\title{
Effect of conjugated linoleic acid on inhibition of prolyl hydroxylase 1 in hearts of mice
}

Jize Zhang ${ }^{1}$ and Defa $\mathrm{Li}^{1,2^{*}}$

\begin{abstract}
Background: Results from different trails have provided evidence of protective effects of cis-9,trans-11-conjugated linoleic acid (CLA) on cardiovascular diseases. But the inhibition of prolyl hydroxylase 1 (PHD1) associated with induction of hypoxia inducible factors (HIFs) by CLA in these protective effects has never been reported before. The objective of this study was to evaluate if the two predominant cis-9, trans-11 (c9, t11), trans-10,cis-12 (t10, c12) CLA isomers and mixture of these two isomers can inhibit PHD1 with induction of HIFs in myocardium in mice and subsequent effects on myocardium metabolism.

Results: CLA mixture and C9, t11 CLA inhibited PHD1 protein expression and increased the levels of protein and mRNA in HIF-2 $\alpha$ in myocardium in mice. Meanwhile, CLA mixture and C9, t11 CLA also elevated the expression of HIF related transcriptional factors like PDK4 and PPAR $\alpha$. The reprogramming of basal metabolism in myocardium in mice was shown on increasing of GLUT4 gene expression by C9, t11 CLA supplemented group. UCP2 was increased by CLA mixture and C9, t11 CLA for attenuating production of ROS.

Conclusion: CLA mixture and C9, t11 CLA could inhibit PHD1 and induce HIF-2 $\alpha$ in myocardium in mice, which is associated with upregulation of PDK4 by activation of PPAR $\alpha$. This process also implies a reprogramming of basal metabolism and oxidative damage protection in myocardium in mice. All the effects shown in hearts of mice are due to $\mathrm{C} 9$, t11 CLA but not t10, C12 CLA.
\end{abstract}

Keywords: CLA, HIF-2a, PDK4, PPARa

\section{Background}

Heart disease like myocardial infarction (MI) or acute myocardial infarction (AMI) and heart ischemia commonly are known as cardiovascular diseases (CVDs), which are the interruption of blood supply to part of the heart, causing heart cells to die. In 2008, an estimated 17.3 million people died from CVDs in the world, in which over $80 \%$ of CVD deaths take place in low-and middle-income countries [1].

Oxygen availability is insufficient when inadequate blood supply happens. Cells undergo adaptive changes in gene expression that promote survival in low oxygen (hypoxic) environment. Cellular adaptation to oxygen availability is mediated by the hypoxia inducible factors (HIFs), a member of the basic helix-loop-helix-PAS

\footnotetext{
* Correspondence: Defali@public2.bta.net.cn

${ }^{1}$ National Key Laboratory of Animal Nutrition, College Animal Science and Technology, China Agricultural University, Beijing 100193, People's Republic of China

Full list of author information is available at the end of the article
}

superfamily which transactivate a host of genes in the nucleus involved in the adaption of hypoxic stress [2]. HIF consists of an unstable $\alpha$ subunit and a stable $\beta$ subunit that binds DNA at specific locations termed hypoxia response elements (HERs) to regulate many genes expression related to hypoxia [3]. HIF- $\alpha$ subunit is regulatory and unique to the hypoxic response. HIF- $\beta$ subunit is constitutive and also involved in xenobiotic response. Three different genes encoding HIF- $\alpha$ subunit are found in mammals: HIF- $1 \alpha$, HIF- $2 \alpha$ and HIF-3 $\alpha$ [2]. HIF- $\alpha$ proteins are maintained at low steady-state level under normoxic condition via hydroxylation by HIF prolyl hydroxylases (PHDs) [4]. Among these three HIF- $\alpha$ isoforms, HIF- $2 \alpha$ in particular shows a unique ability to induce metabolic reprogramming, which ultimately makes mitochondrion harmless but less active in certain conditions by regulating expression of numerous genes [5]. PHDs are 2-oxoglutarate dioxygenases, which are present in three forms in mammals, designated PHD1, PHD2 and PHD3 [6]. Hydroxylated HIF recruits the
C Biomed Central

C 2012 Zhang and Li; licensee BioMed Central Ltd. This is an Open Access article distributed under the terms of the Creative Commons Attribution License (http://creativecommons.org/licenses/by/2.0), which permits unrestricted use, distribution, and reproduction in any medium, provided the original work is properly cited. 
E3-ubiquitin ligase, von Hippel-Lindau protein ( $\mathrm{pVHL}$ ) $[7,8]$, which in turn tags HIF with ubiquitin groups and targets it for degradation by proteasome $[9,10]$.

Many cardiovascular diseases including anemia, myocardial infarction and stroke are linked to inadequate tissue oxygen. So, up-regulation of HIFs by inhibition of PHDs may have beneficial effect on therapy for hypoxia dependent process involved in cardiovascular disease [10]. The availability of less cumbersome non-toxic inhibitors of PHDs has been proved very useful for therapeutic intervention [11-13].

Conjugated linoleic acid (CLA) refers to a group of positional and geometric isomers of the essential fatty acid-linoleic acid (LA), which is produced by the bacterial biohydrogenation of linoleic acid in the gut of ruminant animals via an enzymatic isomerase reaction [14]. CLA is found naturally in food products from these animals predominantly as the cis-9,trans-11 form, whereas synthetic CLA preparations consist of a few different isomers with approximately equal amount of cis-9,trans11 and trans-10,cis-12 CLA [15].

Since be found from 1980s, many research has been done with biological functions of these two predominant isomers of CLA. These isomers are both biologically active and known to have different physiological effects [16]. The original discovery of CLA was as an anticancer component, which was proven to be an effective prevention tool in a number of animal cancer models, such as skin, colon, mammary, lung and liver $[17,18]$. Both isomers have proven to be effective in prevention of cancer, while others reported differences in anti-cancer activities between these isomers [19,20]. t10, c12 CLA was reported to prevent cardiovascular disease [21,22] and reduce body fat in animals [23], which is one of the most important activities of CLA. While c9, t11 CLA was not responsible for these effects [24,25]. There was also research about CLA that it can reduce inflammatory and improve immune response [26-28]. But the controversy was that $\mathrm{t} 10, \mathrm{c} 12$ CLA induced inflammatory responses in white adipose tissue [29]. Besides positive effects induced by CLA, there were also negative effects reported for CLA, especially t10, c12 CLA. Mice fed with CLA mixture or t10, c12 CLA resulted in lipodystrophy, hyperinsulinemia and liver steatosis, whereas, c9, t11 CLA had no negative effect like t10,12 CLA [30-32].

There was research reported that c9, t11 CLA in adipose tissue was associated with a lower risk of MI in basic [33]. But the mechanism of this protective effect is still not fully defined. We estimated that CLA may have influence on PHDs, which is related to the protective effect on myocardium. The mice model was used by supplementing with individual isomers of CLA and the mixture of these two isomers in the diet to determine if these effects are associated with role of prolyl hydroxylase inhibitor on myocardium.

\section{Material and method Material}

Semipurified diet (TD.04460) was from Harlan Teklad (Madison, WI). Antibodies for prolyl hydroxylase 1 (PHD1) and glyceraldehyde 3-phosphate dehydrogenase (GAPDH) were purchased from Bethyl (Montgomery, TX). Antibodies for hypoxia inducible factor-2 alpha (HIF-2 $\alpha$ ), peroxisome proliferator-activated receptor alpha (PPAR $\alpha$ ) and secondary antibody coupled to horse radish peroxidase (HRP) were purchased from Abcam (Cambridge, MA). Other solvents used were purchased from either Sigma Chemical Co. (St. Louis, MO) or Fisher Scientific (Pittsburg, PA).

\section{Animal and diet}

Forty six-month old female ICR mice were randomized into four groups of ten mice each. Animals were housed in individual wire-bottomed cages in a temperature-controlled, humidified room maintained on a $12 \mathrm{~h}$ on/off light cycle and were provided free access to food and water. The mice were fed a semipurified powered diet (TD.04460) (Table 1). Diets were prepared at the beginning of the study and kept at $-20^{\circ} \mathrm{C}$ until use. Fresh diet was provided three times a week. After 1 week adaptation, animals were fed one of the following diets; control, $0.5 \%$ CLA mixture (Mixture), and 0.20\% cis-9,trans-11 CLA (c9, t11 CLA), or $0.20 \%$ trans-10, cis-12 CLA (t10, c12 CLA). $0.20 \%$ of the individual isomers are equivalent to the levels found in $0.5 \%$ CLA mixture diet. Body weight was measured weekly. All CLA preparations were purchased from Natural ASA (Hovdebygda, Norway). The composition of the CLA preparations is given in Table 2.

\section{Sacrifice and tissue sample collection}

After 8 weeks, animals were sacrificed by $\mathrm{CO}_{2}$ asphyxiation after $4 \mathrm{~h}$ fasting. Hearts were removed and frozen

Table 1 TD.04460 Basal Mix (94\%)

\begin{tabular}{ll}
\hline Formula & $\mathbf{g} / \mathbf{K g}$ \\
\hline Casein, "Vitamin-Free" Test & 206.39 \\
L-Cystine & 3.192 \\
Corn Starch & 357.377 \\
Maltodextrin & 140.43 \\
Sucrose & 93.1 \\
Soybean Oil & 95.75 \\
Cellulose & 53.2 \\
Mineral Mix, W/o Ca (04374) & 37.24 \\
Vitamin Mix, AlN-93-VX (94047) & 10.64 \\
Choline Bitartrate & 2.66 \\
TBHQ, antioxidant & 0.021 \\
\hline
\end{tabular}


Table 2 Composition (\%) of CLA Preparations Used in this study

\begin{tabular}{cccc}
\hline & \multicolumn{3}{c}{ CLA preparation } \\
\hline FA & $\mathbf{> 9 0 \%} \mathbf{~ c 9 , ~ t 1 1 ~}$ & $\mathbf{> 9 0 \%} \mathbf{~ t 1 0 , ~ c 1 2}$ & Mixture \\
\hline C9, t11 CLA & 88.6 & 5.7 & 44.3 \\
t10, C12 CLA & 3.0 & 89.5 & 43.9 \\
Oleic acid (18:1) & 3.7 & 1.6 & 5.5 \\
other & 3.7 & 3.2 & 6.3 \\
\hline
\end{tabular}

${ }^{a}$ Analytical data provided by Natural ASA (Hovdebygda, Norway)

by immersion in liquid $\mathrm{N}_{2}$, stored at $-80^{\circ} \mathrm{C}$ until needed for analysis.

\section{mRNA expression analysis}

From frozen hearts, mRNA expression levels of hypoxia inducible factor-1 alpha (HIF-1 $\alpha$ ), endothelial PAS domain-containing protein 1 (EPAS1), aryl hydrocarbon receptor nuclear translocator 2 (ARNT2), egl nine homo$\log 2$ (EGLN2), pyruvate dehydrogenase kinase 4 (PDK4), peroxisome proliferator-activated receptor alpha (PPAR $\alpha)$, carnitine palmitoyltransferase $1 \mathrm{~b}(\mathrm{CPT} 1 \mathrm{~b})$, glucose transporter type 4 (GLUT4), uncoupling protein 2 (UCP2) were analyzed by real-time PCR using StepOnePlus ${ }^{\mathrm{TM}}$ RealTime PCR System with StepOne Software v2.0 (Applied Biosystems, Foster City, CA), TaqMan ${ }^{\circledR}$ Gene Expression Master Mix (Applied Biosystems, Foster City, CA) and TaqMan Gene Expression Assays (Applied Biosystems, Foster City, CA). Total RNA from heart was isolated with Trizol Reagent (Invitrogen, Carlsbad, CA) according to the manufacturer's instructions. Total RNA was reverse-transcribed using High Capacity cDNA Reverse Transcription kit (Applied Biosystems, Foster City, CA). The reference sequence for the mRNAs, the housekeeping gene control (GAPDH) is shown in Table 3.

\section{Western blot analysis}

Tissue lysates were prepared in homogenization buffer [50 $\mathrm{mM}$ Tris- $\mathrm{HCl} \mathrm{pH} \quad 7.5,10 \%(\mathrm{v} / \mathrm{v})$ glycerol, $5 \mathrm{mM}$

Table 3 Information of gene primers used for RT-PCR

\begin{tabular}{ccccc}
\hline Gene & Assay ID & RefSeq & $\begin{array}{c}\text { Exon } \\
\text { Boundary }\end{array}$ & $\begin{array}{c}\text { Assay } \\
\text { Location }\end{array}$ \\
\hline ARNT2 & Mm00476004_m1 & $12-13$ & 1343 \\
CPT1b & Mm00487200_m1 & NM_009948.2 & $17-18$ & 2228 \\
EGLN2 & Mm00519067_m1 & NM_053208.4 & $2-3$ & 1227 \\
EPAS1 & Mm01236112_m1 & NM_010137.3 & $6-7$ & 1192 \\
GLUT4 & Mm00436615_m1 & NM_009204.2 & $9-10$ & 1328 \\
HIF-1 $\alpha$ & Mm00468869_m1 & NM_010431.2 & $4-5$ & 879 \\
HIF-3 $\alpha$ & Mm00469373_m1 & $10-11$ & 1407 \\
PDK4 & Mm01166879_m1 & NM_013743.2 & $3-4$ & 454 \\
PPAR $\alpha$ & Mm00440939_m1 & NM_011144.6 & $7-8$ & 1371 \\
UCP2 & Mm00627597_m1 & NM_011671.4 & $1-2$ & 119 \\
GAPDH & & NM_008084.2 & & \\
\hline
\end{tabular}

magnesium acetate, $0.2 \mathrm{mM}$ EDTA, $0.5 \mathrm{mM}$ dithiothreitol (DTT), $1 \mathrm{mM}$ phenylmethylsulfonyl fluoride (PMSF)] and centrifuged at 12,000 r.p.m. for $20 \mathrm{~min}$ at $4^{\circ} \mathrm{C}$. Protein concentration was determined by Bio-Rad protein assay (Hercules, CA) using $1.4 \mathrm{mg} / \mathrm{mL}$ bovine serum albumin (BSA) as the standard. Proteins $(25 \mu \mathrm{g})$ from each sample were separated on SDS-PAGE and transferred to PVDF membranes (Millipore, Billerica, MA). After blocking with a specific primary antiserum in Tris buffered saline (TBS) containing $0.05 \%$ Tween-20 (TBS-T) and 5\% non-fat dry milk at $4^{\circ} \mathrm{C}$ overnight, the membrane was incubated with each antibody (anti-PHD1, anti-HIF-2 $\alpha$, anti-PPAR $\alpha$, antiGAPDH) at $4^{\circ} \mathrm{C}$ overnight. Finally, after three washes with TBS-T, the blots were incubated with secondary antibody coupled to HRP for $1 \mathrm{~h}$ at room temperature, visualized using ECL Plus Western Blotting Detection System (GE Healthcare, Buckinghamshire, UK) and quantified by Kodak Image Station Software (Scion, Frederick, MD). Relative protein levels were determined by comparison to GAPDH band intensity, which was used as internal control for western blotting analysis.

\section{Statistical analysis}

Data are shown as means and standard errors. All analyses were carried out using SAS software (Version 9.2, SAS institute Inc., Cary, NC) by one-way analysis of variance (ANOVA) followed by Tukey's multiple comparison test.

\section{Results}

\section{Body weight}

No significant difference in body weight was observed with the exception of week 4, where CLA mixture-fed animal had significant lower weight compared to control (Table 4).

\section{Gene expressions of HIFs and PHD1}

The effect of individual isomers of CLA and CLA mixture on gene expressions of three types of HIF- $\alpha$ subunits, HIF- $\beta$ subunit and HIF- $\alpha$ subunit hydroxylase were determined. As shown in Figure 1A, c9, t11 CLA had effect on HIF- $1 \alpha$ gene expression. As seen in Figure 1B, 1 -fold increase in EPAS1 (HIF-2 $\alpha$ ) gene expression was noted in mice fed with c9, t11 CLA and the same effect was also seen in CLA mixture-fed mice $(P<0.05)$. HIF$3 \alpha$ gene expression was undetermined among all treatments. ARNT2 (HIF- $\beta$ ) and EGLN2 (PHD1) gene expressions were unaltered by all treatment (Figure $1 \mathrm{C}$ and $1 \mathrm{D}$ ).

\section{Protein expressions of HIF-2 $\alpha$ and PHD1}

After determining the effect of individual isomers of CLA and CLA mixture on HIFs and PHD1 in mRNA level, protein expressions of HIF- $2 \alpha$ and PHD1 from animals were also determined. As shown in Figure 2A 
Table 4 Effect of individual isomers of CLA and CLA mixture on body weight in the mice

\begin{tabular}{|c|c|c|c|c|c|c|c|c|c|}
\hline Diet & BW0 & BW1 & BW2 & BW3 & BW4 & BW5 & BW6 & BW7 & BW8 \\
\hline Control & $25.90 \pm 0.65^{a}$ & $29.68 \pm 0.44^{a}$ & $29.49 \pm 0.51^{a}$ & $30.19 \pm 0.60^{a}$ & $30.40 \pm 0.64^{a}$ & $30.29 \pm 0.41^{a}$ & $31.94 \pm 0.44^{a}$ & $32.93 \pm 0.52^{a b}$ & $33.17 \pm 0.58^{\mathrm{ab}}$ \\
\hline CLA mixture & $25.90 \pm 0.65^{\mathrm{a}}$ & $28.58 \pm 0.46^{a}$ & $28.03 \pm 0.58^{\mathrm{a}}$ & $28.68 \pm 0.68^{\mathrm{a}}$ & $28.44 \pm 0.77^{b}$ & $29.29 \pm 0.77^{a}$ & $32.00 \pm 0.73^{\mathrm{a}}$ & $32.30 \pm 0.71^{b}$ & $31.88 \pm 0.79^{b}$ \\
\hline$c 9, \mathrm{t} 11 \mathrm{CLA}$ & $25.92 \pm 0.65^{\mathrm{a}}$ & $29.82 \pm 0.61^{\mathrm{a}}$ & $29.41 \pm 0.68^{a}$ & $30.23 \pm 0.62^{a}$ & $29.93 \pm 0.67^{\mathrm{ab}}$ & $30.04 \pm 0.82^{\mathrm{a}}$ & $32.36 \pm 0.69^{a}$ & $34.36 \pm 0.82^{\mathrm{a}}$ & $34.29 \pm 0.89^{a}$ \\
\hline $\mathrm{t} 10,12 \mathrm{CLA}$ & $25.63 \pm 0.63^{\mathrm{a}}$ & $29.31 \pm 0.41^{\mathrm{a}}$ & $28.92 \pm 0.43^{\mathrm{a}}$ & $29.79 \pm 0.45^{\mathrm{a}}$ & $29.20 \pm 0.32^{a b}$ & $30.93 \pm 0.32^{\mathrm{a}}$ & $32.82 \pm 0.41^{\mathrm{a}}$ & $34.05 \pm 0.44^{\mathrm{ab}}$ & $33.26 \pm 0.60^{a b}$ \\
\hline
\end{tabular}

Body weight (BW) in grams was measured weekly (0-8 weeks). Female mice were fed one of the treatment diets for 8 weeks: control, $0.5 \%$ CLA mixture, $0.2 \%$ c9, $\mathrm{t} 11 \mathrm{CLA}$ and $0.2 \% \mathrm{t} 10, \mathrm{C} 12 \mathrm{CLA}$. Values within a column not sharing a common superscript letter indicate significant difference at $P<0.05$. Numbers are mean \pm S.E. $(n=10)$

and $2 \mathrm{C}$, the highest PHD1 protein expression was observed in control-fed animal compared to other groups. The effect of CLA mixture and c9, t11 CLA on increasing HIF- $2 \alpha$ protein expression was shown in Figure $2 \mathrm{~B}$ and $2 \mathrm{E}$.
Gene and protein expressions of PPAR $\alpha$ pathway

As recently noted [5], enhanced expressions of PDK4 and PPAR $\alpha$ associated with stabilized HIF- $2 \alpha$ were shown in mouse skeletal muscle. To determine if the effect of individual isomers of CLA and CLA mixture on stabilization
A. HIF-1 $\alpha$

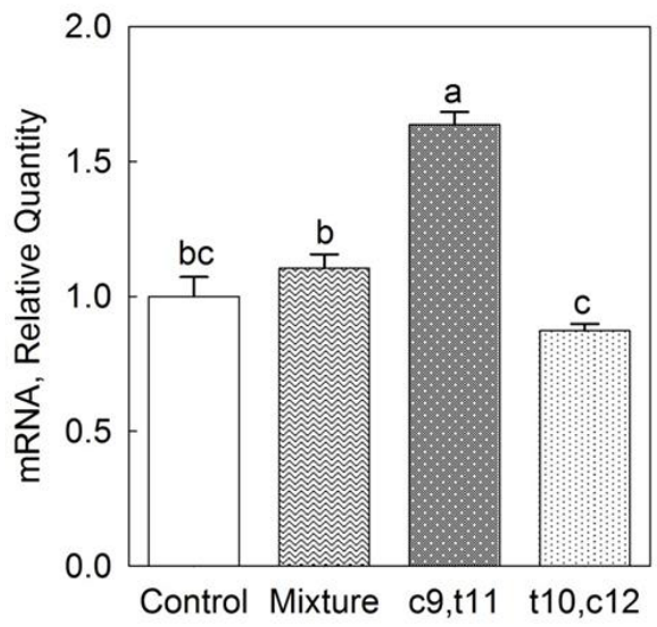

C. ARNT2

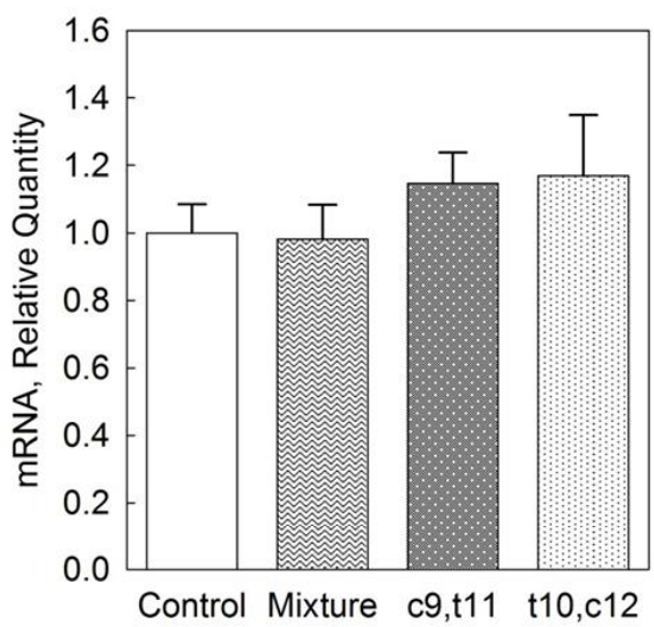

B. EPAS1

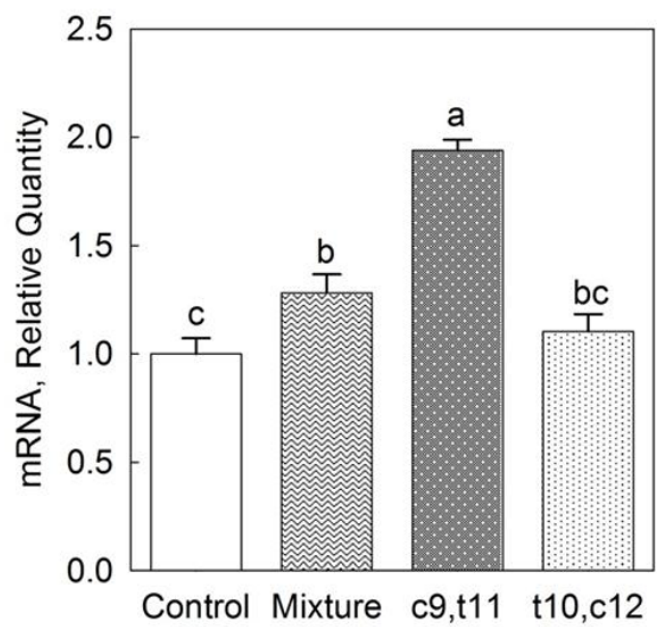

D. EGLN2

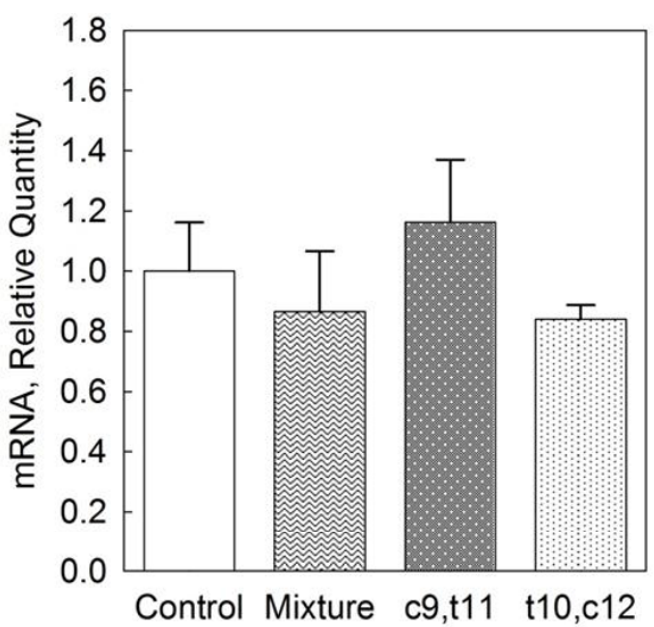

Figure 1 Effects of individual isomers of CLA and CLA mixture on gene expressions of HIFs and PHD1 from the heart: (A) HIF-1 $\alpha$, (B) EPAS1 (HIF-2 $\alpha$ ), (C) ARNT2 (HIF- $\beta$ ) and (D) EGLN2 (PHD1). Female mice were fed one of the treatment diets for 8 weeks: control, $0.5 \%$ CLA mixture, $0.2 \%$ $\mathrm{C} 9, \mathrm{t} 11 \mathrm{CLA}$ and $0.2 \% \mathrm{t10}, \mathrm{c} 12 \mathrm{CLA}$. Different letters in each figure indicate significant difference at $P<0.05$. Numbers are mean \pm S.E. $(\mathrm{n}=5)$. 
A.

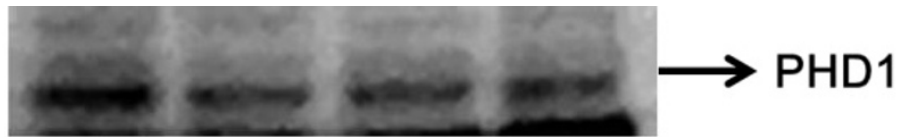

B.

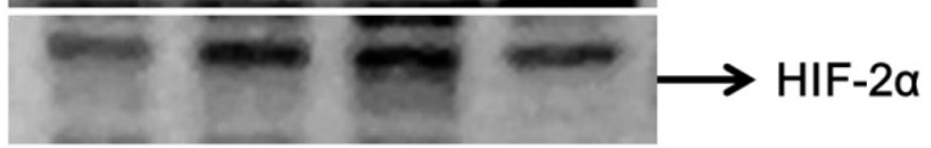

C.

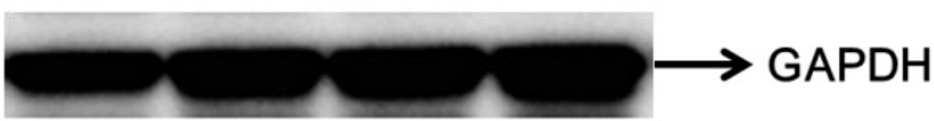

Control Mixture c9,t11 t10,c12

\section{PHD1}

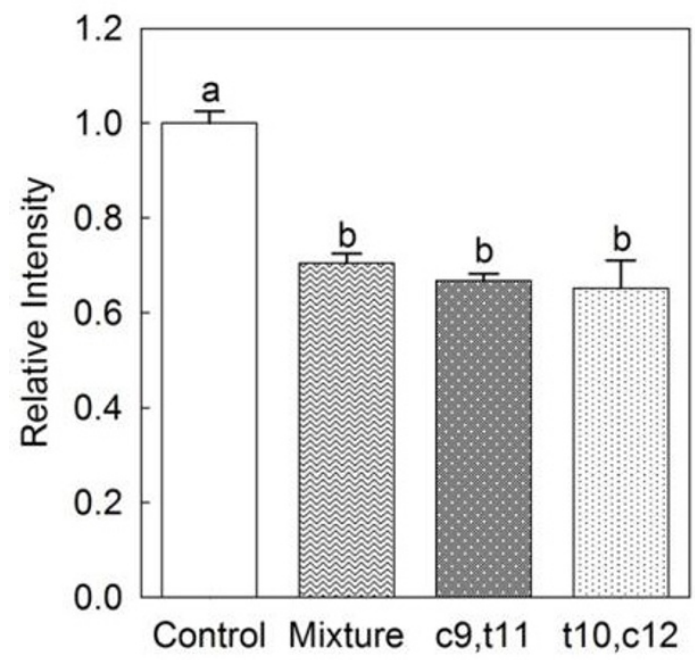

E. HIF-2 $\alpha$

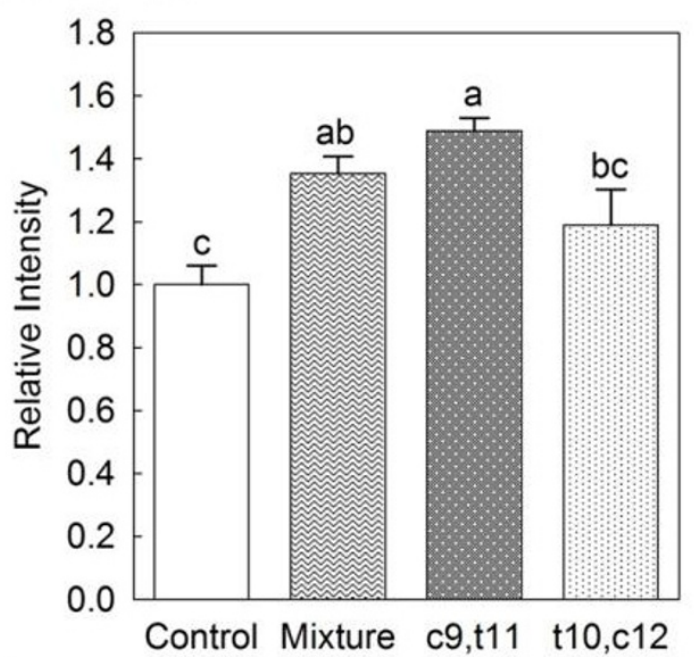

Figure 2 Effects of individual isomers of CLA and CLA mixture on protein expressions from the heart: (A) PHD1 and (B) HIF-2 $\alpha$; relative band intensity statistical results: (D) PHD1 and (E) HIF-2 $\alpha$. (C) GAPDH was used as internal control for western blotting analysis. Female mice were fed one of the treatment diets for 8 weeks: control, 0.5\% CLA mixture, 0.2\% C9, t11 CLA and 0.2\% t10, c12 CLA. Different letters in each figure indicate significant difference at $P<0.05$. Numbers are mean \pm S.E. $(n=3)$.

of HIF- $2 \alpha$ might be mediated by PPAR $\alpha$ pathway, PDK4 and PPAR $\alpha$ expressions in myocardium in mice were measured. Compared with control group $(P<0.05)$, a significant elevation of PDK4 gene expression was evident in mice fed with CLA mixture and c9, t11 CLA, as shown in Figure 3A. The same trend of PPAR $\alpha$ gene expression was also observed as PDK4 gene expression $(P<0.05)$ (Figure 3B). Similar as PPAR $\alpha$ gene expression, CLA mixture, c9, t11 CLA but also 10,12 CLA increased PPAR $\alpha$ protein expression in comparison with control (Figure $3 \mathrm{C}$ and $3 \mathrm{D}$ ).

\section{Gene expressions of glucose and lipid metabolism enzymes}

As a marker for glucose metabolism, GLUT4 gene expression was only increased by c9, t11 CLA fed group compared with the other groups $(P<0.05)$ (Figure $4 \mathrm{~A})$.
For a key enzyme of fatty acid $\beta$-oxidation, CPT1b gene expression was not altered by all treatments (Figure 4B). CLA mixture and c9, t11 CLA significantly increased UCP2 gene expression $(P<0.05)$ relative to control and t10, c12 CLA fed animals (Figure 4C).

\section{Discussion}

In this study, CLA mixture and the two predominant isomers of CLA showed the ability to inhibit PHD1 protein expression. But interestingly, only CLA mixture and c9, t11 CLA played a role in stabilizing HIF-2 $\alpha$ in the normoxia environment and affected expressions of HIF related transcriptional genes with inhibition of PHD1 in hearts of mice. This is a new discovery of well-studied CLA on myocardium protective effect.

One of the important effects of CLA is on decreasing body weight gain, which was proved in various animal 

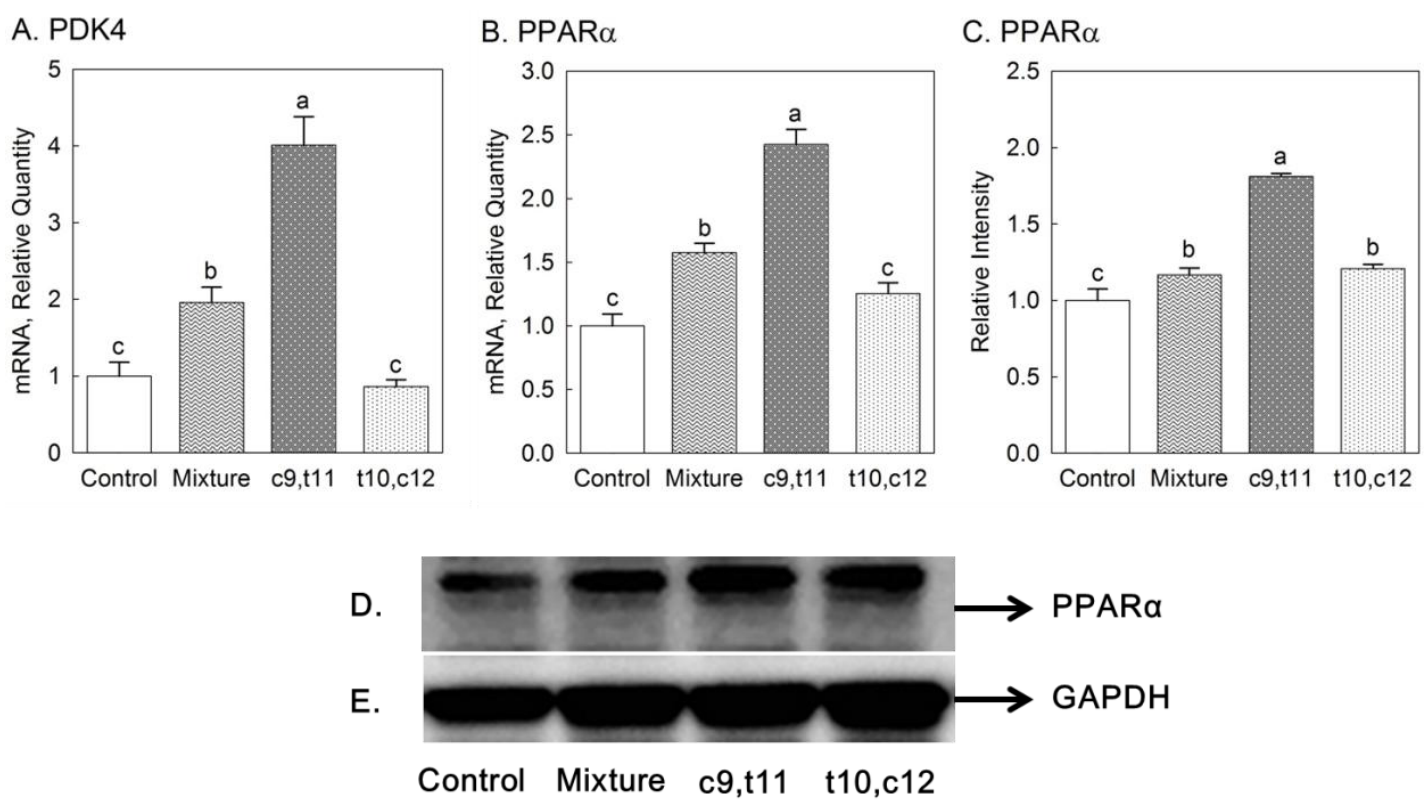

Figure 3 Effects of individual isomers of CLA and CLA mixture on gene and protein expressions of PPAR $\alpha$ pathway from the heart: (A) PDK4 gene expression, (B) PPAR $\alpha$ gene expression, (C) protein relative band intensity statistical result of PPAR $\alpha$ and (D) PPAR $\alpha$ protein expression. (E) GAPDH was used as internal control for western blotting analysis. Female mice were fed one of the treatment diets for 8 weeks: control, $0.5 \%$ CLA mixture, $0.2 \% \mathrm{c} 9, \mathrm{t} 11 \mathrm{CLA}$ and $0.2 \% \mathrm{t} 10, \mathrm{C} 12 \mathrm{CLA}$. Different letters in each figure indicate significant difference at $P<$ 0.05. Numbers are mean \pm S.E. ( $n=5$ for gene expressions and $n=3$ for protein expression).

models like mice and rats [25,34]. However, these findings were shown when those animals were given high amount of CLA, in which t10, c12 CLA was contributed to this effect $[35,36]$. When animals were supplemented with low amount of CLA mixture $(\leq 0.5 \%$ in the diet) or the two predominant isomers of CLA, the body weights were not affected [37-39], which is consistent with our study.

Since PHD1 is a direct oxygen sensor, alternation of expression of PHD-1 is expected to change hypoxic adaptation [40]. Most of the PHD inhibitors reported so far, e.g. DMOG [41], 3,4-DHB [42], FG-0041 [43] are chemicals. None of them is from natural food like CLA which is contained in milk or beef. Inhibition of PHD1 associated with stabilized expression HIF- $2 \alpha$ expression in normoxia condition was seen in CLA mixture and c9, t11 CLA fed mice, which is consistent with a former study that mice lacking PHD1 (PHD1-null mice) showed significant expression of HIF- $2 \alpha$ in the absence of hypoxia [5].

Specifically, CLA mixture and c9, t11 CLA increased HIF- $\alpha$ expression like HIF- $1 \alpha$ and HIF- $2 \alpha$ in mRNA or protein level. The protective effect of HIFs within different tissues has already been noted before $[5,44,45]$. However, there is a debate about the expression of HIF- $\alpha$ in mRNA and in protein level. Research indicated that there was no significant increase in the mRNA expression of EPAS1 $[46,47]$. This may be due to posttranscriptional regulation as found in specific cell types $[48,49]$. From the results showing in the experiment, the regulation of expression of EGLN2 (PHD1) in different levels may share the same mechanism as HIF- $\alpha$. Interesting, t10, c12 CLA also down-regulated PHD1 protein expression, but it was not as potent as 19, t11 CLA on EPAS1 expression, which may be the difference of bioactivity of these two isomers of CLA. In general, HIF- $\beta$ is constitutively expressed and heterodimerizes with HIF- $\alpha$ subunit in the nucleus to form a complex, which binds to hypoxiaresponsive elements in enhancers and promoters of oxygen-responsive genes under hypoxic conditions [47]. Consistent with the former research, the expression of ARNT2 was not altered by all treatments in this study.

The possible mechanism inducing protective effect of HIFs, especially HIF- $2 \alpha$, is linked to an increase in the expression of PDK4 [50]. In the normoxic environment, pyruvate enters the tricarboxylic acid (TCA) cycle inside the mitochondrion where it generates ATP in the presence of oxygen. But with the inhibition of PHD1 or in the hypoxia environment like heart ischemia, entry of pyruvate is restricted by expression of PDK4, which is associated with induction of HIF- $2 \alpha[5,51]$. In this study, PDK4 gene expression was upregulated in mice fed with CLA mixture and c9, t11 CLA.

PPAR $\alpha$ is known to activate the PDK4 gene [51]. Research on the hibernating mammal model also showed the level of PDK4 mRNA increased greatly by activation 
A. GLUT4

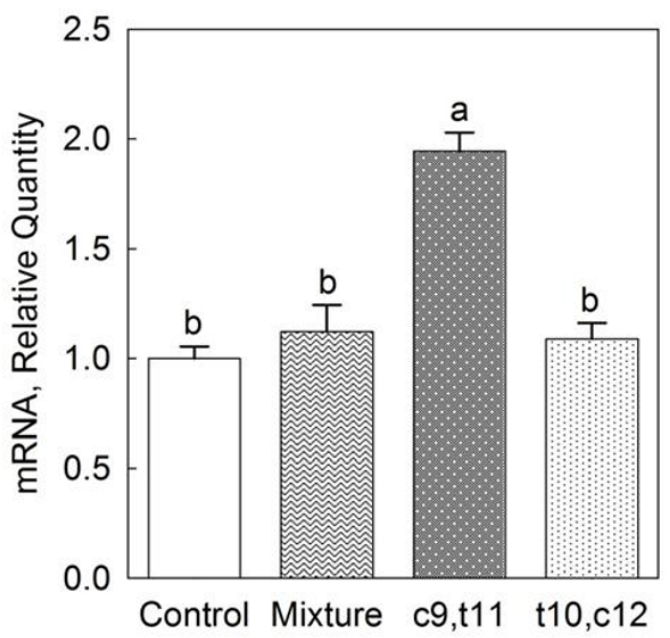

C. UCP2

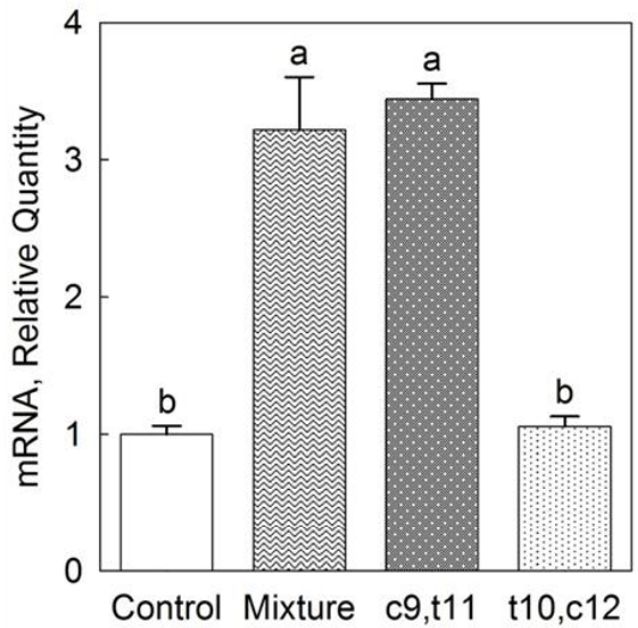

B. CPT1b

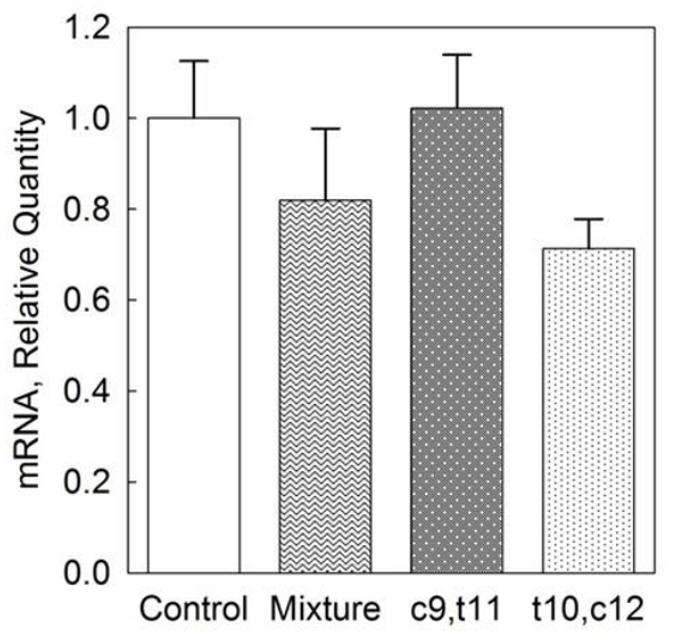

Figure 4 Effects of individual isomers of CLA and CLA mixture on gene expressions of glucose and lipid metabolism enzymes from the heart: (A) GLUT4, (B) CPT1b and (C) UCP2. Female mice were fed one of the treatment diets for 8 weeks: control, $0.5 \%$ CLA mixture, 0.2\% C9, t11 CLA and 0.2\% t10, C12 CLA. Different letters in each figure indicate significant difference at $P<0.05$. Numbers are mean \pm S.E. ( $\mathrm{n}=5$ ).

of PPAR $\alpha$ during hibernation [52]. Hearts from PPAR agonist clofibrate-treated rats had an improved recovery of post-ischemic contractile function and reduced ische$\mathrm{mia} /$ reperfusion (I/R)-induced infarct size. The coincident upregulation of PPAR $\alpha$ and PDK4 in PHD1deficient was also demonstrated by knockdown of PPAR $\alpha$ in muscles of PHD1-deficient mice in vivo and feeding wild-type mice with PPAR $\alpha$ agonist [5]. In this study, we found that CLA mixture and the two predominant isomers of CLA significantly increased PPAR $\alpha$ protein expression. This result, combined with PDK4 gene expression and HIF-2 $\alpha$ expression, suggests that PPAR $\alpha$ activated by CLA mixture and c9, t11 CLA, with induction of HIF-2 $\alpha$, can initiate PDK4 gene expression.
Induction of HIF- $2 \alpha$ by inhibition of PHD1 implies a reprogramming of basal metabolism in mice, especially in energy production and utilization like glucose metabolism and fatty acid metabolism. Glycolytic flux was increased in mouse muscle fiber in low oxygen conditions [5]. As a marker for glucose metabolism, c9, t11 CLA fed mice increased GLUT4 gene expression significantly in this study. Combined, c9, t11 CLA may induce more glucose entering cell cytoplasm to generate ATP by glycolysis when PHD1 was inhibited. But for t10, c12 CLA, which promoted dysregulation of lipid and glucose metabolism in hepatic tissue while c9, t11 CLA had not effect [32]. There was also another research reported that mice supplemented 0.5\% CLA mixture showed different 
effect on GLUT4 gene expression in adipose and skeletal muscle tissue [53]. All the evidences showed in experiments suggested that the two predominant isomers of CLA may have diverse effect on glucose metabolism in different tissues. CPT1b is known as a rate-limiting enzyme in fatty acid $\beta$-oxidation which transfers fatty acids through mitochondrial membrane to be oxidized within the mitochondrial matrix [54]. A former research showed that fatty acid oxidation was not altered in PHD1-deficient mice [5], which is consistent with our research that CPT1 mRNA expression was not changed during PHD1 inhibition by CLA mixture and the two predominant isomers of CLA supplementation in the diet.

As an important energy expenditure parameter, the effect of uncoupling proteins (UCPs) has become prominent in the field of thermogenesis, especially UCP1 [55]. But for UCP2 and UCP3, there is a consensus that the primary function of UCP2 and UCP3 is to attenuate mitochondrial production of free radical to protect against oxidative damage, degenerative disease and aging rather than to promote gross thermogenesis or energetic inefficiency [56,57]. Oxidative damage caused by reactive oxygen species (ROS) is produced in mitochondrion, which can trigger the toxic effects living with oxygen. In contrast, oxygen depletion (hypoxia) also increases mitochondrial ROS that is detrimental to cells unless attenuated [58]. In this study, the UCP2 gene expression in mice fed with CLA mixture and c9, t11 CLA was elevated greatly, which is consistent with former research done on effect of elucidating UCP2 on attenuating ROS production $[59,60]$.

\section{Conclusion}

To our knowledge, this study is the first to examine the effect of CLA on inhibition of PHD1 in vivo. One of the two predominant isomers of CLA- c9, t11 CLA showed more potent effect than the other CLA isomer- $t 10, \mathrm{c} 12$ CLA. This inhibitory effect is associated with induction of HIF-2 $\alpha$. Several lines of evidence suggest the protective effect of c9, t11 CLA on inhibition of PHD1 plays a part by upregulation of PDK4 gene expression, which is activated by PPAR $\alpha$. This process can imply a reprogramming of basal metabolism in hearts of mice by increasing glycolysis. Meanwhile, c9, t11 CLA also increased UCP2 gene expression to attenuate the damage of ROS. This study provides a new interpretation of protective effect in myocardium in vivo by CLA, especially one of the predominant isomers-c9, t11 CLA.

\section{Acknowledgements}

The author is grateful for the suggestions during drafting manuscript by Dr. Linda Meccouri.

\section{Author details}

'National Key Laboratory of Animal Nutrition, College Animal Science and Technology, China Agricultural University, Beijing 100193, People's Republic of China. ${ }^{2}$ College Animal Science and Technology, 2-Yuan-Ming-Yuan West Rd., Haidian District, Beijing 100193, China.

\section{Authors' contributions}

JZZ and DFL conceived the study and design. JZZ has performed all experiments and analyzed data, interpreted results and written the final draft of this manuscript. All authors have read and approved the final manuscript.

\section{Competing interests}

The authors declare that they have no competing interests.

Received: 17 December 2011 Accepted: 7 February 2012 Published: 7 February 2012

\section{References}

1. Global atlas on cardiovascular disease prevention and control: WHO; World Heart Federation; World Stroke Organization 2011

2. Maxwell: Hypoxia-inducible factor as a physiological regulator. Exp Physiol 2005, 90(6):791-797.

3. Wiesener MS, Maxwell PH: HIF and oxygen sensing; as important to life as the air we breathe? Ann Med 2003, 35(3):183-190.

4. Jaakkola P, Mole DR, Tian YM, Wilson MI, Gielbert J, Gaskell SJ, Kriegsheim A, Hebestreit HF, Mukherji M, Schofield CJ, Maxwell PH, Pugh CW, Ratcliff PJ: Targeting of HIF-alpha to the von Hippel-Lindau ubiquitylation complex by $\mathrm{O}_{2}$-regulated prolyl hydroxylation. Science 2001, 292(5516):468-472.

5. Aragonés J, Schneider M, Van Geyte K, Fraisl P, et al: Deficiency or inhibition of oxygen sensor Phd1 induces hypoxia tolerance by reprogramming basal metabolism. Nat Genet 2008, 40:170-180.

6. Epstein AC, Gleadle JM, MCNeill LA, Hewitson KS, O'Rourke J, Mole DR, Mukherji M, Metzen E, Wilson MI, Dhanda A, Tian YM, Masson N, Hamilton DL, Jaakkola P, Barstead R, Hodgkin J, Maxwell PH, Pugh CW, Schofield CJ, Ratcliffe PJ: C. Elegans EGL-9 and mammalian homologs define a family of dioxygenases that regulate HIF by prolyl hydroxylation. Cell 2001, 107(1):43-54.

7. Hon WC, Wilson MI, Harlos K, Claridge TDW, Schofield CJ, Pugh CW, Maxwell PH, Ratcliffe PJ, Stuart DI, Jones EY: Structural basis for the recognition of hydroxyproline in HIF-1 alpha by pVHL. Nature 2002, 417:975-978.

8. Ivan $\mathrm{M}$, Kondo $\mathrm{K}$, Yang H, Kim W, Valiando J, Ohh M, Salic A, Asara JM, Lane WS, Kaelin WG: HIFa targeted for VHL-mediated destruction by proline hydroxylation: implications for $\mathrm{O}_{2}$ sensing. Science 2001, 292(5516):464-468

9. Maxwell PH, Wiesener MS, Chang GW, Clifford SC, Vaux EC, Cockman ME, Wykoff CC, Pugh CW, Maher ER, Ratcliffe RJ: The tumour suppressor protein VHL targets hypoxia-inducible factors for oxygen-dependent proteolysis. Nature 1999, 399:271-275.

10. Ohh M, Park CW, Ivan M, Hoffman MA, Kim TY, Huang LE, Pavletich N, Chau V, Kaelin WG: Ubiquitination of hypoxia-inducible factor requires direct binding to the beta-domain of the von Hippel-Lindau protein. Nat Cell Biol 2000, 2(7):423-427.

11. Kaelin William G Jr, Ratcliffe Peter J: Oxygen Sensing by Metazoans: The Central Role of the HIF Hydroxylase Pathway. Mol Cell 2008, 30(4):393-402.

12. Giaccia A, Siim BG, Johnson RS: HIF-1 as a target for drug development. Nat Rev Drug Discov 2003, 2(10):803-811.

13. Hewitson KS, Schofield CJ: The HIF pathway as a therapeutic target. Drug Discov Today 2004, 9(16):704-711.

14. Kepler CR, Hirons KP, McNeill JJ, Tove SB: Intermediates and products of biohydrogenation of linoleic acid by Butyrivibrio fibrisolven. J Biol Chem 1966, 241:1350-1354

15. Priza MW, Park Y, Cook ME: The biologically active isomers of conjugated linoleic acid. Prog Lipid Res 2001, 40(4):283-298.

16. Priza MW, Park Y, Cook ME: Mechanisms of action of conjugated linoleic acid: evidence and speculation. Proc Soc Exp Biol Med 2000, 223(1):8-13.

17. Lee KW, Lee HJ, Cho HY, Kim YJ: Role of the conjugated linoleic acid in the prevention of cancer. Crit Rev Food Sci Nutr 2005, 45(2):251-258.

18. Kelly NS, Hubbard NE, Erickson KL: Conjugated linoleic acid isomers and cancer. J Nutr 2007, 137(12):2599-2607. 
19. Ip C, Dong Y, Ip MM, Banni S, Carta G, Angioni E, Murru E, Spada S, Melis MP, Saebo A: Conjugated linoleic acid isomers and mammary cancer prevention. Nutr Cancer 2002, 43(1):52-58.

20. Masso-Welch PA, Zangani D, Ip C, Vaughan MM, Shoemaker S, Ramirez RA, Ip MM: Inhibition of angiogenesis by the cancer chemopreventive agent conjugated linoleic acid. Cancer Res 2002, 62(15):4383-4389.

21. Lee KN, Pariza MW, Ntambi JM: Conjugated linoleic acid decreases hepatic stearoyl-CoA desaturase mRNA expression. Biochem Biophys Res Commun 1998, 248(3):817-821.

22. Kritchevsky D, Tepper SA, Wright S, Czarnecki SK, Wilson TA, Nicolosi RJ: Conjugated linoleic acid isomer effects in atherosclerosis: growth and regression of lesions. Lipids 2004, 39(7):611-616.

23. Park Y, Pariza MW: Mechanisms of body fat modulation by conjugated linoleic acid (CLA). Food Res Int 2007, 40(3):311-323.

24. Arbonés-Mainar JM, Navarro MA, Acín S, Guzmán MA, Arnal C, Surra JC, Carnicer R, Roche HM, Osada J: Tran-10, ci-12- and ci-9, tran-11conjugated linoleic acid isomers selectively modify HDL-apolipoprotein composition in apolipoprotein E knockout mice. J Nutr 2006, 136(2):353-359.

25. Park Y, Storkson JM, Albright KJ, Liu W, Pariza MW: Evidence that the trans10 , cis-12 isomer of conjugated linoleic acid induces body composition changes in mice. Lipids 1999, 34(3):235-241.

26. Cook ME, Miller CC, Park Y, Pariza M: Immune modulation by altered nutrient metabolism: nutritional control of immune-induced growth depression. Poult Sci 1993, 72(7):1301-1305.

27. Bassaganya-Riera J, Hontecillas R, Beitz DC: Colonic anti-inflammatory mechanisms of conjugated linoleic acid. Clin Nutr 2002, 21(6):451-459.

28. Luongo D, Bergamo P, Rossi M: Effects of conjugated linoleic acid on growth and cytokine expression in Jurkat T cells. Immunol Lett 2003, 90(2-3):195-201.

29. Poirier H, Shapiro JS, Kim RJ, Lazar MA: Nutritional supplementation with tran-10, ci-12-conjugated linoleic acid induces inflammation of white adipose tissue. Diabetes 2006, 55(6):1634-1641

30. Tsuboyama-Kasaoka N, Takahashi M, Tanemura K, Kim HJ, Tange T, Okuyama H, Kasai M, Ikemoto S, Ezaki O: Conjugated linoleic acid supplementation reduces adipose tissue by apoptosis and develops lipodystrophy in mice. Diabetes 2000, 49(9):1534-1542

31. Clément $L$, Poirier $H$, Niot I, Bocher V, Guerre-Millo M, Krief S, Staels B, Besnard P: Dietary trans-10, cis-12 conjugated linoleic acid induces hyperinsulinemia and fatty liver in the mouse. J Lipid Res 2002, 43(9):1400-1409.

32. Navarro MA, Badimon L, Rodriguez C, Arnal C, Noone EJ, Roche HM, Osada J, Martinez-Gonzalez J: Trans-10, cis-12-CLA dysregulate lipid and glucose metabolism and induce hepatic NR4A receptors. Front Biosci (Elite Ed) 2010, 2:87-97.

33. Smit LA, Baylin A, Campos $H$ : Conjugated linoleic acid in adipose tissue and risk of myocardial infarction. Am J Clin Nutr 2010, 92(1):34-40.

34. West DB, Delany JP, Camet PM, Blohm F, Truett AA, Scimeca J: Effects of conjugated linoleic acid on body fat and energy metabolism in the mouse. Am J Physiol 1998, 275(3 Pt 2):R667-672.

35. Park Y, Albright KJ, Liu W, Storkson JM, Cook ME, Pariza MW: Effect of conjugated linoleic acid on body composition in mice. Lipids 1997, 32(8):853-858.

36. Terpstra AH, Beynen AC, Everts $H$, Kocsis S, Katan MB, Zock PL: The decrease in body fat in mice fed conjugated linoleic acid is due to increases in energy expenditure and energy loss in the excreta. J Nutr 2002, 132:940-945.

37. Bissonauth V, Chouinard Y, Marin J, Leblanc N, Richard D, Jacques $H$ : The effects of t10, c12 CLA isomer compared with c9, t11 CLA isomer on lipid metabolism and body composition in hamsters. $J$ Nutr Biochem 2006, 17(9):597-603.

38. de Deckere EA, van Amelsvoort JM, McNeill GP, Jones P: Effects of conjugated linoleic acid (CLA) isomers on lipid levels and peroxisome proliferation in the hamster. Br J Nutr 1999, 82(4):309-317.

39. Sisk MB, Hausman DB, Martin RJ, Azain MJ: Dietary conjugated linoleic acid reduces adiposity in lean but not obese Zucker rats. J Nutr 2001, 131:1668-1674

40. Berra $E$, Ginouvès $A$, Pouysségur J: The hypoxia-inducible-factor hydroxylases bring fresh air into hypoxia signaling. EMBO Rep 2006, 7(1):41-45.
41. Lomb David J, Desouza Lynette A, Franklin James L, Freeman Robert S: Prolyl hydroxylase inhibitors depend on extracellular glucose and Hypoxia-Inducible Factor (HIF)-2 to inhibit cell death caused by Nerve Growth Factor (NGF) deprivation: evidence that HIF-2 has a role in NGFpromoted survival of sympathetic neurons. Mol Pharmacol 2009, 75(5):1198-1209.

42. Ivan M, Haberberger T, Gervasi DC, Michelson KS, Gunzler V, Kondo K, Yang H, Sorokina I, Conaway RC, Conaway JW, Kaelin WG Jr: Biochemical purification and pharmacological inhibition of a mammalian prolyl hydroxylase acting on hypoxia-inducible factor. Proc Natl Acad Sci 2002, 99:13459-13464.

43. Warnecke C, Griethe W, Weidemann A, Jurgensen JS, Willam C, Bachmann S, Ivashchenko Y, Wagner I, Frei U, Wiesener M, Eckardt KU: Activation of the hypoxia-inducible factor-pathway and stimulation of angiogenesis by application of prolyl hydroxylase inhibitors. FASEB J 2003, 17(9):1186-1188.

44. Hyvarinen Jaana, Hassinen Ellmo, Sormunen Raija, Maki MJoni, Kivirikko IKari, Koivunen Peppi, Myllyharju Johanna: Hearts of hypoxia-inducible factor prolyl 4-hydroxylase-2 hypomorphic mice show protection against acute ischemia-reperfusion injury. J Biol Chem

45. Natarajan R, Salloum FN, Fisher BJ, Kukreja RC, Fowler AA: Hypoxia inducible factor-1 activation by prolyl 4-hydroxylase-2 gene silencing attenuates myocardial ischemia reperfusion injury. Circ Res 2006, 98(1):133-140.

46. Forsyth NR, Kay A, Hampson K, Downing A, Talbot R, McWhir J: Transcriptome alterations due to physiological normoxic $\left(2 \% \mathrm{O}_{2}\right)$ culture of human embryonic stem cells. Regen Med 2008, 3:817-833.

47. Westfall SD, Sachdev S, Das P, Hearne LB, Hannink M, Roberts RM, Ezashi T: Identification of oxygen-sensitive transcriptional programs in human embryonic stem cells. Stem Cells Dev 2008, 17:869-882.

48. Huang LE, Gu J, Schau M, Bunn HF: Regulation of hypoxia-inducible factor 1alpha is mediated by an O2-dependent degradation domain via the ubiquitin-proteasome pathway. Proc Natl Acad Sci USA 1998, 95(14):7987-7992.

49. Lang KJ, Kappel A, Goodall GJ: Hypoxia-inducible factor-1alpha mRNA contains an internal ribosome entry site that allows efficient translation during normoxia and hypoxia. Mol Biol Cell 2002, 13(5):1792-1801.

50. Kelly D: Hypoxic reprogramming. Nat Genet 2008, 40(2):132-134.

51. Wu P, Peters JM, Harris RA: Adaptive increase in pyruvate dehydrogenase kinase 4 during starvation is mediated by peroxisome proliferatoractivated receptor alpha. Biochem Biophys Res Commun 2001, 287(2):391-396.

52. Buck MJ, Squire TL, Andrews MT: Coordinate expression of the PDK4 gene: a means of regulating fuel selection in a hibernating mammal. Physiol Genomics 2002, 8(1):5-13.

53. Park Y, Park Y: Conjugated nonadecadienoic acid is more potent than conjugated linoleic acid on body fat reduction. J Nutr Biochem 2010, 21(8):764-773.

54. McGarry D, Brown NF: The Mitochondrial Carnitine Palmitoyltransferase System-From Concept to Molecular Analysis. Eur J Biochem 1997, 244(1):1-14.

55. Brand MD, Esteves TC: Physiological functions of the mitochondrial uncoupling proteins UCP2 and UCP3. Cell Metab 2005, 2(2):85-93.

56. Brand MD, Pamplona R, Portero-Otín M, Requena JR, Roebuck SJ, Buckingham JA, Clapham JC, Cadenas S: Oxidative damage and phospholipid fatty acyl composition in skeletal muscle mitochondria from mice underexpressing or overexpressing uncoupling protein 3. Biochem J 2002, 368(Pt 2):597-603.

57. Casteilla L, Rigoulet M, Pénicaud L: Mitochondrial ROS metabolism: modulation by uncoupling proteins. IUBMB life 2001, 52(3-5):181-188

58. Guzy RD, Schumacker PT: Oxygen sensing by mitochondria at complex III: the paradox of increased reactive oxygen species during hypoxia. Exp Physiol 2006, 91(5):807-819.

59. Arsenijevic D, Onuma H, Pecqueur C, Raimbault S, Manning BS, Miroux B, Couplan E, Alves-Guerra MC, Goubern M, Surwit R, Bouillaud F, Richard D, Collins S, Ricquier D: Disruption of the uncoupling protein-2 gene in mice reveals a role in immunity and reactive oxygen species production. Nat Genet 2000, 26(4):435-439. 
60. Cortez-Pinto H, Zhi Lin H, Qi Yang S, Odwin Da Costa S, Diehl AM: Lipids up-regulate uncoupling protein 2 expression in rat hepatocytes. Gastroenterol 1999, 116(5):1184-1193.

doi:10.1186/1476-511X-11-22

Cite this article as: Zhang and Li: Effect of conjugated linoleic acid on inhibition of prolyl hydroxylase 1 in hearts of mice. Lipids in Health and Disease 2012 11:22

Submit your next manuscript to BioMed Central and take full advantage of:

- Convenient online submission

- Thorough peer review

- No space constraints or color figure charges

- Immediate publication on acceptance

- Inclusion in PubMed, CAS, Scopus and Google Scholar

- Research which is freely available for redistribution 